\title{
Food Consumption Patterns of Male and Female Undergraduate Students in Indonesia During New Normal Implementation of Pandemic Covid-19 Era
}

Kiki Kristiandi ${ }^{1 *}$, Andi Eka Yunianto ${ }^{2}$, Made Darawati ${ }^{3}$, Tetty Herta Doloksaribu ${ }^{4}$, Ike Anggraeni ${ }^{5}$, Muksin Pasambuna ${ }^{6}$, Oon Fatonah Akbarini ${ }^{7}$

${ }^{1}$ Departement of Food Agroindustry, States Polytechnic of Sambas, Sambas, Indonesia; ${ }^{2}$ Departement of Nutrition, Siliwangi University, Tasikmalaya, Indonesia; ${ }^{3}$ Departement of Nutrition, Polythecnic of Health Mataram, Mataram, Indonesia; ${ }^{4}$ Departement of Nutrition, Polythecnic of Health Medan, Medan, Indonesia; ${ }^{5}$ Departement of Public Health, University Mulawarman, Samarinda, Indonesia; ${ }^{6}$ Departement of Nutrition, Polytechnic of Health Manado, Mando, Indonesia; ${ }^{7}$ Departement of Midwifery, Polytechnic of Health Pontianak, Pontianak, Indonesia

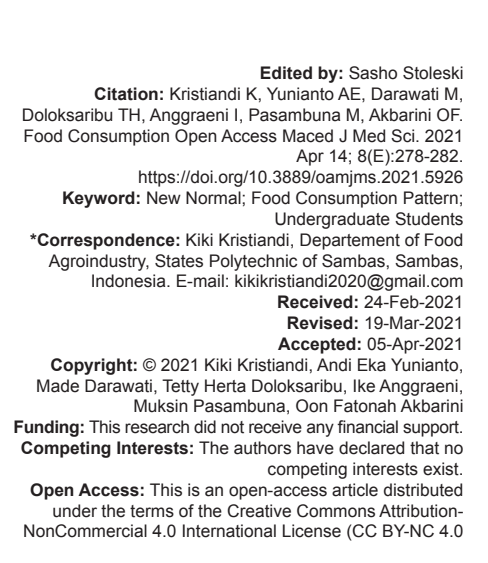

Abstract

AIM: This study aimed to analyze the description of Indonesian undergraduate students' food consumption patterns during the COVID-19 period.

METHODS: The design used was cross-sectional with random sampling technique. The correlation test was ChiSquare and analyzed using univariate. The respondents involved were 17-24 years old with 5924 persons; active undergraduate students. Questionnaires were distributed using Google form.

RESULTS: The results indicated a relationship between gender and major, education level, social status, and funds source $(p=0.000)$. However, sex and residence did not correlate $(p=0.16)$. The same was revealed between gender with consumption patterns, carbohydrates, animal protein, vegetable protein, vegetables, fruit, snacks, water, and supplements.

CONCLUSION: Overall, during the new normal period of pandemic COVID-19 era, student food consumption patterns could be categorized as healthier lifestyle changes. Thus, the undergraduate students are suggested to maintain a diverse and balanced diet to boost their immunity optimally.

\section{Introduction}

Food consumption is a basic human need that can affect a person's nutritional status. Undergraduate students are vulnerable to nutrition since their growth and development period and require sufficient energy to support activities [1]. If the consumption received does not follow the needs, it will disrupt the growth and development that cannot be optimal [2]. The need for suitable food consumption is guided by balanced nutrition [3].

Consumption of proper food can help maintain physical health and support learning abilities and daily activities [4]. During the COVID-19 pandemic, it was necessary to balance food consumption to maintain body immunity [5]. Along with proper and varied food consumption, immunity will be maintained so that students can ward off diseases and other types of infections [6]. However, if already infected, the healing will be quicker [7].
Facing the spread of COVID-19 pandemic and the level of student activity is dense, it is necessary to support suitable food consumption to maintain the endurance and support regular exercise [8]. Suggested that apart from providing healthy food, supplements, and vitamins also recommended maintaining cleanliness by washing hands with soap, wearing masks, and maintaining distance [9].

Covid-19 has caused many changes in various sectors and made restrictions on a large scale so that changes in daily patterns must adjust to the COVID19 period [9]. The condition in COVID-19 era changed all orders, and all patterns must undergo adjustments, including the world of higher education. Indonesian higher education currently requires students to study at home and stop student activities related to direct physical contact. This situation lets the researchers who observe the food consumption patterns of Indonesian undergraduate students during the COVID-19 period. This study aimed to determine the food consumption 
patterns of Indonesian undergraduate students during the COVID-19 era.

\section{Methods}

\section{Design, time, and location}

This research was conducted in June 2020 with a cross-sectional design. The respondents involved in the study were Indonesian undergraduate students, selected by random sampling technique. They were 17-23 years old, hold an active student status, and willing to fill out a questionnaire by signed out the informed consent available on the Google form. This study was involving 5924 respondents. The data retrieval was carried out by questionnaires distributed through WhatsApp media.

\section{Data processing and analysis}

The data processing in this study included coding, entry, cleaning, and analysis. The data collected was processed and analyzed using the Microsoft Excel 2013 computer program. These variables include gender, major, education level, food expenditure, non-food expenditure, social status, source of funds, residence, food frequency, carbohydrates, animal protein, vegetable protein, vegetable, fruit, snacks, water, and supplements. The statistical analysis applied in this study was univariate using SPPS version 21 through Chisquare test.

\section{Results}

\section{Characteristic of samples}

The sample involved in this study was 5924 people. Characteristically, the sample represented in Table 1 was dominated by women and most of from health major study program (3982 samples). Based on the education level, there were 2529 samples from bachelor degree level, 2169 samples from Diploma 3 (D3) level, and 1226 samples from Diploma 4 (D4) education level. According to social status, mostly sample was in the middle category (4180 people). The source of funds received by the sample during education was from families (5287 people). About 5287 samples during education in the COVID-19 period stayed with their family. It indicated that all Indonesia education during the pandemic underwent a learning process from their respective homes and supported to prevent coronavirus infections.

\section{Table 1: Sample characteristics}

\begin{tabular}{|c|c|c|c|c|c|c|c|}
\hline \multirow[t]{2}{*}{ Characteristic } & \multicolumn{2}{|l|}{ Male } & \multicolumn{2}{|c|}{ Female } & \multicolumn{2}{|l|}{ Total } & \multirow[t]{2}{*}{$p$-value } \\
\hline & $n$ & $\%$ & $\mathrm{n}$ & $\%$ & $n$ & $\%$ & \\
\hline \multicolumn{8}{|l|}{ Major } \\
\hline Health & 300 & 7.5 & 3682 & 92.5 & 3982 & 100 & \multirow[t]{2}{*}{0.000} \\
\hline Non-health & 545 & 28.0 & 1397 & 72.0 & 1942 & 100 & \\
\hline \multicolumn{8}{|l|}{ Education level } \\
\hline Diploma 3 (D3) & 210 & 9.7 & 1959 & 90.3 & 2169 & 100 & \multirow[t]{3}{*}{0.000} \\
\hline Diploma 4 (D4) & 138 & 11.2 & 1088 & 88.8 & 1226 & 100 & \\
\hline Bachelor degree & 497 & 19.7 & 2032 & 80.3 & 2529 & 100 & \\
\hline \multicolumn{8}{|l|}{ Social status } \\
\hline Lower class & 120 & 19.0 & 511 & 81.0 & 631 & 100 & \multirow[t]{3}{*}{0.000} \\
\hline Middle class & 588 & 14.1 & 3592 & 85.9 & 4180 & 100 & \\
\hline Upper class & 137 & 12.0 & 976 & 88.0 & 1113 & 100 & \\
\hline \multicolumn{8}{|l|}{ Source of funds } \\
\hline Family & 678 & 13.0 & 4609 & 87.0 & 5287 & 100 & \multirow[t]{6}{*}{0.000} \\
\hline Working & 76 & 35.3 & 139 & 64.7 & 215 & 100 & \\
\hline Scholarship & 73 & 21.6 & 266 & 78.4 & 339 & 100 & \\
\hline Loan & 2 & 14.3 & 12 & 85.7 & 14 & 100 & \\
\hline Personal savings & 15 & 28.8 & 37 & 71.2 & 52 & 100 & \\
\hline Social assistance & 1 & 5.8 & 16 & 94.2 & 17 & 100 & \\
\hline \multicolumn{8}{|l|}{ Residence } \\
\hline Boarding house & 344 & 13.8 & 2147 & 86.2 & 2491 & 100 & \multirow[t]{4}{*}{0.16} \\
\hline Family & 406 & 14.9 & 2309 & 85.1 & 2715 & 100 & \\
\hline Dormitory & 92 & 13.0 & 617 & 87.0 & 709 & 100 & \\
\hline others & 3 & 33.3 & 6 & 66.7 & 9 & 100 & \\
\hline
\end{tabular}

\section{Food consumption pattern}

According to Table 2, regarding the food consumption pattern during the COVID-19 pandemic, the frequency of eating among undergraduate students was 2-3 time meals with a sample size of 5364 respondents. It was mostly found in female respondents.

Table 2 shows that the undergraduate students' food consumption patterns for the carbohydrate group frequency were 2-3 times, dominated by 4706 female respondents and 4033 male respondents. The frequency of food consumption by Indonesian undergraduate students originated from animal food was 2-3 times with a total sample of 3872 people and the dominant by the female (3380 respondents). Table 2 shows that the frequency of Indonesian undergraduate students in the vegetable protein food consumption was 2-3 times, 3451 samples. Vegetable protein intake had a significant relationship and was correlated with gender $(p=0.000)$. High consumption of vegetable protein brings various health benefits and is one solution for avoiding animal protein consumption. The advantages of vegetable protein are maintaining body, supporting heart health, maintaining concentration, and other advantages. Based on the data shown in Table 2, the total sample was 3555 people with the frequency of vegetable consumption about $2-3$ times and dominated by female respondents (3077 persons).

Table 2 shows that data for the snack consumption pattern of Indonesian undergraduate students were 1 time. It was different with several previous studies; the contribution of snacking one's nutritional fulfillment during adolescence tends to be higher than that of staple foods. Meanwhile, students' most commonly consumed supplements were vitamins with a total sample of 2898 persons, and 1855 samples did not consume any supplement. It indicated that it had become necessary for students to maintain health and keep the body healthy. Some samples that did not take supplements (1855 respondents) could be due to the 
Table 2: Food consumption patterns of Indonesian students during the COVID-19 pandemic

\begin{tabular}{|c|c|c|c|c|c|c|c|}
\hline \multirow[t]{2}{*}{ Food frequency } & \multicolumn{2}{|c|}{ Male } & \multicolumn{2}{|c|}{ Female } & \multicolumn{2}{|l|}{ Total } & \multirow[t]{2}{*}{$p$-value } \\
\hline & $n$ & $\%$ & $n$ & $\%$ & $\mathrm{n}$ & $\%$ & \\
\hline \multicolumn{8}{|l|}{ Food consumption } \\
\hline 1 time & 34 & 14.2 & 205 & 85.8 & 239 & 100 & \multirow[t]{3}{*}{0.044} \\
\hline $2-3$ time & 750 & 14.0 & 4614 & 86.0 & 5364 & 100 & \\
\hline$>3$ time & 61 & 19.0 & 260 & 81.0 & 321 & 100 & \\
\hline \multicolumn{8}{|l|}{ Carbohydrate } \\
\hline 1 time & 65 & 11.4 & 507 & 88.6 & 572 & 100 & \multirow[t]{3}{*}{0.035} \\
\hline $2-3$ time & 673 & 14.3 & 4033 & 85.7 & 4706 & 100 & \\
\hline$>3$ time & 107 & 16.6 & 539 & 83.4 & 646 & 100 & \\
\hline \multicolumn{8}{|l|}{ Animal protein } \\
\hline 0 time & 15 & 28.8 & 37 & 71.2 & 52 & 100 & \multirow[t]{4}{*}{0.000} \\
\hline 1 time & 226 & 18.0 & 1031 & 82.0 & 1257 & 100 & \\
\hline $2-3$ time & 492 & 12.7 & 3380 & 87.3 & 3872 & 100 & \\
\hline$>3$ time & 112 & 15.1 & 631 & 84.9 & 743 & 100 & \\
\hline \multicolumn{8}{|l|}{ Vegetable protein } \\
\hline 0 time & 50 & 26.5 & 139 & 73.5 & 189 & 100 & \multirow[t]{4}{*}{0.000} \\
\hline 1 time & 223 & 13.7 & 1404 & 86.3 & 1627 & 100 & \\
\hline $2-3$ time & 469 & 13.6 & 2982 & 86.4 & 3451 & 100 & \\
\hline$>3$ time & 103 & 15.7 & 554 & 84.3 & 657 & 100 & \\
\hline \multicolumn{8}{|l|}{ Vegetables } \\
\hline 0 time & 43 & 23.8 & 138 & 76.2 & 181 & 100 & \multirow[t]{4}{*}{0.000} \\
\hline 1 time & 206 & 16.0 & 1079 & 84.0 & 1285 & 100 & \\
\hline $2-3$ time & 478 & 13.4 & 3077 & 86.6 & 3555 & 100 & \\
\hline$>3$ time & 118 & 13.1 & 785 & 86.9 & 903 & 100 & \\
\hline \multicolumn{8}{|l|}{ Fruit } \\
\hline 0 time & 152 & 21.2 & 566 & 78.8 & 718 & 100 & \multirow[t]{4}{*}{0.000} \\
\hline 1 time & 394 & 14.1 & 2395 & 85.9 & 2789 & 100 & \\
\hline $2-3$ time & 243 & 13.1 & 1618 & 86.9 & 1861 & 100 & \\
\hline$>3$ time & 56 & 10.1 & 500 & 89.9 & 556 & 100 & \\
\hline \multicolumn{8}{|l|}{ Snacks } \\
\hline 0 time & 181 & 21.7 & 655 & 78.3 & 836 & 100 & \multirow[t]{4}{*}{0.000} \\
\hline 1 time & 356 & 13.3 & 2314 & 86.7 & 2670 & 100 & \\
\hline $2-3$ time & 209 & 13.0 & 1397 & 87.0 & 1606 & 100 & \\
\hline$>3$ time & 99 & 12.2 & 713 & 87.8 & 812 & 100 & \\
\hline \multicolumn{8}{|l|}{ Water } \\
\hline$<8$ glasses & 358 & 11.8 & 2676 & 88.2 & 3034 & 100 & \multirow[t]{2}{*}{0.000} \\
\hline$>8$ glasses & 487 & 16.9 & 2403 & 83.1 & 2890 & 100 & \\
\hline \multicolumn{8}{|l|}{ Supplement } \\
\hline Vitamins & 398 & 13.7 & 2500 & 86.3 & 2898 & 100 & 0.000 \\
\hline Minerals & 36 & 16.4 & 184 & 83.6 & 220 & 100 & \\
\hline Spice stew & 37 & 8.6 & 394 & 91.4 & 431 & 100 & \\
\hline Herbs & 31 & 8.8 & 323 & 91.2 & 354 & 100 & \\
\hline Black seed & 3 & 9.7 & 28 & 90.3 & 31 & 100 & \\
\hline Infused water & 4 & 4.4 & 87 & 95.6 & 91 & 100 & \\
\hline No supplement & 326 & 17.6 & 1529 & 82.4 & 1855 & 100 & \\
\hline Others & 10 & 22.7 & 34 & 77.3 & 44 & 100 & \\
\hline
\end{tabular}

lack of knowledge about the benefits of supplements and how to use supplements properly.

\section{Discussion}

Mokoginta et al. explain that a person's health behavior is influenced by the level of education, the better the behavior related to health and well-being [11]. Higher education can help a person make a change in healthy living behavior and regulate consumption patterns. Higher education can achieve a healthy life and plan for a healthy life in the short and long term [11], [12], [13]. Stated that higher education aims to encourage life change by implementing a healthy lifestyle and having a positive attitude toward eating and nutritional intake [9].

The Ministry of Education and Culture of Indonesia issued a letter listed in Number 15 of 2020 and strengthened by Indonesian Minister of Education and Culture's circular, Number 4 of 2020; concerning guidelines for organizing learning from home during the COVID-19 pandemic. Hence, breaking the Covid-19 chain by not doing direct learning. The appeal made by the minister is also responded directly by all universities throughout Indonesia by instructing all learning process activities to be carried out at home. However, the relearning process can be carried out if the higher education area zone is included in the green zone category by establishing a right and correct health protocol.

Food consumption patterns are usually carried out in fulfilling needs, including attitudes, beliefs, and food choices [10]. The factors influencing food consumption are gender, age, education, occupation, knowledge, and taboos [14]. When viewed from the guidelines for balanced dietary nutrition, the recommended frequency of meals is appropriate. It is also supported by Supariasa [15], who explained that the frequency of main meals could affect the total intake of daily energy and nutrients.

Recommends that proper food includes balanced nutrition such as carbohydrates, protein, fat, vitamins, and minerals [9]. Hence, a balanced nutritional pattern can create a robust immune foundation. Rhaisa et al. [16] revealed that staple foods containing carbohydrates are often consumed and have been part of Indonesia's culture for a long time. Carbohydrates are one of the primary sources of energy for the body. Carbohydrate is also part of the fulfillment of balanced nutrition and physical movement and for concentrating while studying [11].

Bogor states that Indonesian people have experienced an increase in animal food consumption of $32.11 \%$ [17]. The importance of animal food as a source of increasing body immunity [12]. Animal food is a food source that contains protein and function as a building block and is needed during growth. Besides, protein can help maintain body tissues and replace damaged cells [6].

Protein is a macronutrient needed by the body in large quantities [10], [13]. Protein intake in an inappropriate amount will have detrimental effects on the body's health [14]. The frequency level of student food consumption is categorized well [9]. The large number of samples consumes vegetables about 2-3 times. The importance of the level of student knowledge about health during the Covid-19 pandemic, a global problem and included non-natural disasters. By consuming enough vegetables to help and maintain normal health in the body because vegetables are one of the intakes that can maintain the balance of the body and complement and prevent the risk of other non-communicable diseases [15]. For fruit food consumption, the frequency of consumption was 1 time. Musyabiq et al. [18] and Viau [19] showed the same data; Indonesian people's fruit consumption is still low, with an average of $83.64 \%$. Based on Llanaj et al. [20], the level of fruit availability is sufficient after rice and grain. Another thing that makes people who lack consumption of fruit is that fruit is not compulsory food for consumption. 
Aulia et al. [21] in her research explained that $>10 \%$ of energy is from snacks and $>5$ times a week and it is $\times 7$ the risk of obesity. Factors affecting the frequency of snacks made by undergraduate students in this study were due to the limited availability and access to snacks since the pandemic COVID-19. Besides, students also had an adequate level of knowledge of the information received.

Furthermore, students' frequency of drinking during the COVID-19 pandemic is < $<$ glasses (3034). Briawan et al. [22] explained in their research that most adolescents 15-24 years had not met their fluid needs according to the recommendation to drink eight glasses of water per day. Students' lack of drinking water frequency is because teenagers currently only consume water when thirsty [16]. The impact of lack of fluids on the body is fatigue and makes the body weak and loses focus and lowers the body's metabolic conditions [22]. However, consuming nutritious food with proper handling will provide more health benefits for the body [17]. Another consideration for many who do not take supplements is knowing the supplement's benefits [18].

\section{Conclusion}

Undergraduate students' consumption pattern during the COVID-19 pandemic was categorized as sufficient and close to the general guidelines for balanced nutrition. The level of undergraduate student awareness of health during the COVID-19 pandemic was excellent. The frequency of eating is in the good category because it is done 2-3 times (Table 2). Food consumption frequency was the same for macronutrient food source groups such as carbohydrates, animal and vegetable protein, and several other food groups. However, still many students did not take any supplement.

\section{References}

1. Guelinckx I, Iglesia I, Bottin JH, De Miguel-Etayo $P$ González-Gil EM, Salas-Salvadó J, et al. Intake of water and beverages of children and adolescents in 13 countries. Eur J Nutr. 2015;54(Suppl 2):69-79. https://doi.org/10.1007/ s00394-015-0955-5

PMid:26072216

2. Harvi SF, Maryanto S, Pontang GS, Program NS, Faculty HS. The correlation between energy and fat of street food towards the nutritional status of students aged 13-15 years old in west ungaran. JGK. 2017;9(21):11-22.

3. Susenas $A D$. Konsumsi pangan masyarakat indonesia analisis data susenas 1999-2005. Gizi Indon. 2007;30(1):47-56. https:// doi.org/10.36457/gizindo.v30i1.40
4. Studi P, Gizi I, Kedokteran F, Diponegoro U. Nutrition college. J Nutr. 2015;m:492-8.

5. Appendix S, Ludvigsson JF. Correspondence open schools Covid-19, and child and teacher morbidity in Sweden. N Engl J Med. 2021;384(7):669-71. https://doi.org/10.1056/ nejmc2026670

PMid:33406327

6. Huseinovic E, Hörnell A, Johansson I, Esberg A, Lindahl B, Winkvist A. Changes in food intake patterns during 2000-2007 and 2008-2016 in the population-based Northern Sweden diet database. Nutr J. 2019;18:36. https://doi.org/10.1186/ s12937-019-0464-0

7. Pratiwi DA. Analisis Faktor-Faktor Perubahan Kebiasaan Makan Mahasiswa PPKU IPB Asal Sumatera Utara. Bogor: IPB University; 2017.

8. Wu YC, Chen CS, Chan YJ. The outbreak of COVID-19: An overview. J Chin Med Assoc. 2020;83(3):217-20.

PMid:32134861

9. World Health Organization. WHO Director-General's Opening Remarks at the Media Briefing on COVID-19-3; April 2020. Available from: https://www.who.int/dg/speeches/detail/whodirector-general-s-opening-remarks-at-the-media-briefingon-covid-19. [Last accessed on $2020 \mathrm{Apr}$ 03]. https://doi. org/10.1093/ww/9780199540884.013.u44226

10. Chu HY, Englund JA, Starita LM, Famulare M, Brandstetter E, Nickerson DA, et al. Early detection of Covid-19 through a citywide pandemic surveillance platform. N Engl J Med. 2020;383(2):185-7. PMid:32356944

11. Mokoginta FS, Manampiring AE. Gambaran Pola Asupan Makanan Pada Remaja di Kabupaten Bolaang Mongondow Utara Kandidat Skripsi Fakultas Kedokteran Universitas Sam Ratulangi Manado Gizi, dan Sangat Penting Untuk Memenuhi Tercapainya Gizi Seimbang Dapat Bermanfaat Untuk Mencegah Terjadin; 2016. https://doi.org/10.35790/ebm.4.2.2016.14618

12. Mahan LK, Raymond JL. Krause's Food and the Nutrition Process. 14th ed. St. Louis, Missouri, AS: Elsevier; 2017.

13. Hassan BK, Cunha DB, Valeria G, Pereira A, Sichieri R. Changes in breakfast frequency and composition during adolescence : The adolescent nutritional assessment longitudinal study, a cohort from Brazil. PLoS One. 2018;13(7):e0200587. https:// doi.org/10.1371/journal.pone.0200587

PMid:30024906

14. Contento IR. Nutrition Education. Mississauga, Ontario, CA: Jones and Bartlett Publishers; 2011.

15. Supariasa ID. Pendidikan dan Konsultasi Gizi. Jakarta, ID: Penerbit Buku Kedokteran EGC; 2013.

16. Rhaisa G, Silva PO, Nakabayashi J, Bandeira V, Toral N, Monteiro R. Family meal frequency and its association with food consumption and nutritional status in adolescents: A systematic review. PLoS One. 2020;15(9):e0239274. https:// doi.org/10.1371/journal.pone.0239274

PMid:32946506

17. Bogor Di. Pola Konsumsi Pangan Hewani Dan Status Giz Remaja Sma Dengan Status Sosial Ekonomi Berbeda; 2010. https://doi.org/10.25182/jgp.2013.8.2.123-128

18. Musyabiq S, Karima N, Graharti R, IImu B, Kerja K, Kedokteran $\mathrm{F}$, et al. Hubungan asupan protein nabati dengan kadar hemoglobin pada wanita usia remaja vegan relationship between vegetable protein intake and hemoglobin levels in vegan adolescence women. Medula. 2019;9:233-6. https://doi. org/10.14710/jnc.v3i4.6890

19. Viau K. Food frequency questionnaire an alternative method to assess protein intake in adolescents and adults with phenylketonuria. Top Clin Nutr. 2014;29(4):332-42. https://doi. org/10.1097/tin.0000000000000014 
20. Llanaj E, Ádány R, Lachat C, Haese MD. Examining food intake and eating out of home patterns among university students. PLoS One. 2018;13(10):e0197874. https://doi.org/10.1371/ journal.pone.0197874

PMid:30296258

21. Aulia F, Effendi H, Padang UN. Review of analysis of performance increasing supplements consumed by factory athletes containing doping indicated substances. J Stamina. 2019;2:41-50.

22. Briawan D, Hardinsyah, Marhamah, Zulaikhah and Aries M. The Consumption of Beverages and Its Preference Among Adolescents Living in Jakarta And Bandung. Gizi Indon, 2011, 34(1):43-51.

23. Nopiyanto YE, Raibowo S, Sugihartono T. Healthy lifestyle with exercise and nutritional intake to increase immunity. Dharm
Raflesia. 2020;18(02):90-100.

24. Mariza YY, Kusumastuti CA. The relationship between breakfast habits and having habits with the nutritional status of basic school children in Pedurungan Sub-District, Semarang City. J Nutr Coll. 2013;2(1):207-13. https://doi.org/10.14710/jnc. v2i1.2108

PMid:30296258

25. Badan Pusat Statistik (Central Bureau of Statistics). Konsumsi Kalori dan Protein Penduduk Indonesia dan Provinsi, Maret 2020 (Consumption of Calories and Protein of the Population of Indonesia and Provinces, March 2020). Available from: https://www.bps.go.id/publication/2020/11/02 dde28c6757a5e3ef908f5452/konsumsi-kalori-dan-proteinpenduduk-indonesia-dan-provinsi-maret-2020.html. [Last accessed on $2021 \mathrm{Feb}$ ] 